\title{
French government shifts accent of spending towards industry
}

Paris

THE 1988 budget proposals presented last week by French minister for research and higher education, Jacques Valade, confirm the government's intention to shift the balance between private- and publicsector science and technology research in France. While several measures are envisaged to encourage industry-sponsored research, growth in state-supported research establishments (grands organismes) has been clearly restricted.

University teaching departments, which lack the infrastructure to carry out research, do slightly better in the budget. Grants for university-based research increases next year by 14 per cent, although this is less than the increase for 1987 ( 25 per cent).

The overall science and technology research budget will increase by 8.5 or 10.5 per cent compared to last year (depending on whether pledged sums are included in calculations), but this includes both civil and defence spending. When civil research alone is considered, the increase is a more modest 3.4 per cent, to FF39,345 million ( $\$ 6,503$ million), against an annual inflation rate of about 2 per cent. Defence research spending, while less than in 1987, will still increase by 10 per cent to FF33,000 million.

Proposed grants to individual research establishments - still to be agreed by the Finance Ministry - vary. The Centre National de la Recherche Scientifique (CNRS), with its associated national institutes, and the Institut National de la Santé et de la Recherche Médicale (INSERM) - the two largest grands organismes can expect increases of about 1 and 3 per cent, respectively. The Institut Français pour l'Exploitation de la Mer (IFREMER) will get an increase of about 2.6 per cent over 1987, while the nation's controversial technology 'shop window', the Cité des Sciences et de l'Industrie, at La Villette, Paris, will have its grant drastically cut by 11 per cent (see Nature 329, 96; 1987).

The lack of government favours for the grands organismes is also seen in the negligible number of new posts for young researchers for $1988-150$ overall, against 398 in 1987. Speaking to the press, Valade considered the creation of new jobs "an achievement", since none had been expected, but forgot to mention the loss of 350 posts at engineer, technician and administrator grades.

Unlike the situation in most Western countries, researchers taken on by the grands organismes have jobs for life. Because of a high intake of new researchers in the 1960 s and early 1980 s, when public sector research had a higher government priority, present research teams are rela-

cively young and senior staff will retire at about the same time, in the late 1990s.

Unions representing researchers, as well as the independent advisory body, the Conseil Supérieur de la Recherche et de la Technologie (CSRT) argue that a much higher annual rate of job creation is necessary to offset the "massive" drop predicted for the end of the century. Valade, on the other hand, feels that "because growth in employment has been high it need not stay high" and wants to see posts liberated by mid-career researchers joining the private sector. Considerable financial incentives have been offered to researchers making such a move, and FF500 million of tax incentives are to be available to companies developing their research activity.

The government emphasis on commercially exploitable research is also apparent in a 50 per cent increase in grants to the Agence Nationale de Valorisation de la Recherche (ANVAR), set up to promote research and development in industry, particularly in association with public sector research groups. ANVAR's grant had previously been cut by 40 per cent when the present government took office last year, revealing a dramatic change in policy towards research.

Grants totalling FF930 million (compared to FF750 million for 1987) have been earmarked for the Fonds de la Recherche et de la Technologie (FRT), a research fund reserved for national priority research programmes. Valade

\section{Franco-German agreement to tap hot rocks}

\section{Paris}

French and West German geological establishments have signed an agreement to collaborate on an exploratory geothermic energy project at Soultz-sousForêts, in the Rhine valley near Mulhouse in Alsace. The first phase of the project, which should be completed in 1989 , will be undertaken by the French Bureau de Recherches Géologiques et Minières (BRGM) and the German Bundesanstalt für Geowissenschaften und Rohstoffe, at a cost of FF50 million ( $\$ 5$ million). The European Economic Community is to contribute FF14 million to the costs from its general research fund, the rest coming from national research budgets - FF16 million from France and FF20 million from West Germany.

The geothermal gradient, around $3{ }^{\circ} \mathrm{C}$ per $100 \mathrm{~m}$, usually makes it impracticable to exploit the Earth's heat energy at the surface, but at Soultz-sous-Forêts, geological anomalies have resulted in temper-

\section{European data net under threat}

\section{London}

Proposals by the West German telecommunications authority, the Bundespost, to impose usage-related charges on top of the costs of leased data lines would, if implemented, have "disastrous consequences" for European academic research, Dennis Jennings, president of the European Academic Research Network (EARN), warned last week. Such action by an individual national authority would undermine strategic research programmes and would be against the best interests of the European community, Jennings says. Last week EARN decided to give up four of the five international leased lines that it runs into West Germany.

announced the 11 rubrics for which tenders may be submitted (by private as well as public sector research groups): (1) biotechnologies, (2) nutrition, (3) medical research (including AIDS and retro-virus research), (4) human sciences, (5) technology and production, (6) electronics and information technology, (7) transport and civil engineering, (8) natural resources and the environment, (9) new materials, (10) new chemistry and (11) development.

Valade singled out research on high temperature superconductors as a prime example of an area where industry and the grands organismes should collaborate. Under the new materials heading of the FRT list of priorities, FF20 million ( $\$ 3.28$ million), will be available, in addition to existing grants to public sector physics and chemistry laboratories. Peter Coles atures of $150{ }^{\circ} \mathrm{C}$ in the underlying granite at a depth of only $1,800-2,000 \mathrm{~m}$. At this temperature the energy can, in principle, be used not only to heat water pumped into the drill hole, but also to generate electricity, using heat-exchanges at the surface. As the Rhine itself forms the frontier between France and Germany in this region, both countries would be able to benefit from the energy if it can be harnessed, hence the decision to collaborate.

Similar projects at Los Alamos in the United States and in Cornwall in Britain encountered serious difficulties in recovering hot water at the surface, but depths are greater than those in Alsace $(3,500$ and $2,500 \mathrm{~m}$, respectively) and because this part of Alsace was also the site of exploratory drilling for oil, its geology is well documented. The disused wells and derricks will be exploited for the initial seismic, hydraulic and corrosion studies comprising phase I of the geothermic projects.

Peter Coles 